\title{
Anu Kantola ja Hanna Kuusela, Huipputuloiset: Suomen rikkain promille
}

Tampere: Vastapaino, 2019, 360 s.

Anu Kantolan ja Hanna Kuuselan haastattelututkimukseen pohjautuvan Huipputuloiset -teoksen lähtökohtana on havainto, että niin Suomessa kuin globaalistikin eniten ansaitsevan prosentin edustajien tulot ovat 1980-luvulta lähtien kasvaneet huomattavasti yleistä tulokehitystä nopeammin. Myös tämän ryhmän sisällä suurituloisimmat ovat edelleen kasvattaneet ansioitaan selkeästi eniten. Herääkin kysymys, onko tämän ryhmän sosiaalinen ja materiaalinen todellisuus eriytymässä muusta yhteiskunnasta. Huipputuloiset ovat myös poikkeuksellisen hyvin edustettuina taloudellisessa ja poliittisessa päätöksenteossa. Näistä syistä Kantola ja Kuusela ovat asettaneet tavoitteekseen selvittää Suomen korkeatuloisimman promillen näkemyksiä tämän päivän suomalaisesta yhteiskunnasta ja heidän omasta paikastaan siinä.

Huipputuloiset on herättänyt runsaasti julkista keskustelua myös akateemisten piirien ulkopuolella. Sen esiin nostamat ilmiöt nähtiin yhteiskunnallisesti merkittäviksi ja ajankohtaisiksi. Verrattain pienilukuinen joukko pääosin talousliberaaleilla mielipiteillä profiloituneita kommentaattoreita on kuitenkin kyseenalaistanut koko tutkimuksen luotettavuuden kohdistamalla kritiikkiä sen otantaan ja toteutukseen (ks. esim. Pursiainen 2019; Siilasmaa 2019). Tätä arvostelua on kuitenkin kirjan sisällön ja tutkimuksen kokonaisuuden pohjalta vaikea nähdä aiheelliseksi.

Teosta varten on haastateltu 90 henkilöä tutkijoiden tunnistamasta 5000 hengen suurituloisimmasta promillesta. Perusjoukon Kantola ja Kuusela koostivat vuosien 2006-17 verotilastojen avulla, joita on täydennetty medialähteistä poimituilla sekä Tilastokeskuksesta kerätyillä tiedoilla. Näin he saivat tunnistettua joukon verrattain pysyvästi Suomen suurituloisimpia henkilöitä.

Sekä tilastollinen työ perusjoukon tunnistamiseksi, että varsinainen datan keräysprosessi, on dokumentoitu hyvin sekä varsinaisessa tekstissä että erillisissä liitteissä kirjan lopussa. Myös datan keräämiseen liittyvät ongelmat, jotka liittyvät lähinnä verotietojen koostamistavoissa tapahtuneisiin muutoksiin ja tiettyjen tulojen jäämiseen niiden ulkopuolelle, on esitetty avoimesti, eikä niiden voi katsoa vaikuttavan merkittävästi lopputuloksiin.

Myös varsinaisen haastatteluotannan kuvaus ja toteutus ovat linjassa muiden vastaavien tutkimusasetelmien kanssa. Noin puolet tutkimukseen pyydetyistä suostui haastatteluun, minkä lisäksi vastanneiden joukko edustaa tilastollisesti varsin hyvin tutkimuksen kohteena olevaa perusjoukkoa. Kuten aiemmassa teosta koskeneessa julkisessa keskustelussa on todettu (ks. Määttänen 2019), tutkimuksen otokseen ja sen edustavuuteen kohdistunut kritiikki on perustunut lähinnä määrällisen ja laadullisen tutkimuksen kriteerien sekoittamiselle. Tällaisen kritiikin motiiveja voidaan pitää osin kyseenalaisina.

Suurituloisimman promillen tilastollinen tarkastelu vahvistaa aikaisempia käsityksiä ryhmän keskimääräisistä edustajista: he ovat iäkkäitä, korkeakoulutettuja, suomalaistaustaisia ja miehiä. Erityisen huomattavaa on, että Suomen suurimmat tulot ansaitaan pääomatuloista, kun taas ammattijohtajille keskittyvät palkkatulot muodostavat ainoastaan neljänneksen eniten ansaitsevan promillen tuloista. 
Tutkimukseen sisällytetyt henkilöt on luokiteltu kolmeen ryhmään: ammattijohtajiin, yrittäjiin ja perijöihin. Nämä ryhmät muodostavat noin kaksi kolmasosaa koko perusjoukosta. Viimeisessä, tutkimuksen ulkopuolelle jääneessä kolmanneksessa pääosa henkilöistä jäi tuntemattomiksi, joskin eräät pienemmät joukot, kuten finanssialan ammattilaiset ja mielenkiintoisesti myös apteekkarit, olivat edustettuina.

Kirjan pääosan muodostaa kahteen päälukuun jakautuva analyysiosio. Analyysin ensimmäinen puolisko käsittelee suurituloisimman promillen edustajien itseymmärrystä ja suhdetta yhteiskuntaan edellä mainittujen kolmen ryhmän kautta. Osiossa nousevat mielenkiintoisella tavalla esiin moraalikäsitykset ja niiden kietoutuminen kunkin ryhmän itsekokemukseen. Haastatteluosioita myös taustoitetaan ansiokkaasti kuvaamalla esimerkiksi yrittäjyyspuheen leviämistä yhä useammille yhteiskunnan osa-alueille ja varallisuuden kasautumista tietyille suvuille.

Ammattijohtajien palkkioiden kasvaminen on saanut runsaasti huomiota julkisessa keskustelussa. Haastatellut johtajat perustelevat tulojaan sillä, kuinka he panostavat lähes koko elämänsä työhön. Työtuntien määrän lisäksi harrastukset suunnitellaan uraa tukeviksi ja perheet jäävät ajankäytössä toiseksi. Kantola ja Kuusela toteavat, että tässä ajattelussa yhdistyy suomalaiseen kulttuuriin kuuluva luterilainen työmoraali ja uudempi, globaalista bisneskulttuurista nouseva ajatus yritysjohtajasta huippu-urheilijan kaltaisena erikoisyksilönä. Molemmat diskurssit toimivat johtajilla sekä motivoijina että oikeuttajina, mahdollistaen näin myös vähemmän työhönsä panostavien ja siksi myös vähemmän ansaitsevien ihmisten moraalisen arvostelun.

Myös suurituloisimpaan promilleen kuuluvien yrittäjien haastatteluissa tutkijat ovat löytäneet jopa kalvinistisen kristillisyyden kaikuja. Toisin kuin armoa korostava luterilaisuus, kalvinismi näkee taloudellisen menestyksen merkkinä moraalisesti oikeasta elämäntavasta ja Jumalan suosiosta. Samoin kuin ammattijohtajat, yrittäjät asettavat huomattavan suuren moraalisen arvon omalle työlleen ja intohimolleen työtään kohtaan, ja arvottavat itseään sen kautta. Mielenkiintoisimpana erona ammattijohtajiin, joiden vertailukohta löytyy usein kansainvälisistä tähtijohtajista, yrittäjät painottavat oman elämänsä tavanomaisuutta, pröystäilemättömyyttä ja keskiluokkaisuutta. He siis samaistavat itsensä keskiluokkaan. Kantola ja Kuusela kiinnittävät myös huomiota haastatteluissa ilmenevään työnteon arvoa koskevaan paradoksiin: suurituloisimpaan promilleen päässeet yrittäjät pitävät tai ovat pitäneet pitkiä sapattivapaita ja eläneet omaisuutensa tuotoilla. Samalla he kuitenkin ovat valmiita moralisoimaan vähemmän ansaitsevien jouten oloa ja "tuottamattomia" elintapoja.

Perintöjen ansiosta suurituloisten henkilöiden itseymmärrys ja suhde ympäröivään yhteiskuntaan poikkeaa selkeästi johtajista ja yrittäjistä. Mielenkiintoisella tavalla heidän tärkeimpänä sosiaalisena kontekstinaan esiintyy suku, jolle perityn omaisuuden katsotaan kuuluvan. Suku on myös eettinen peruste omaisuudelle ja tuloille. Perinnön mukana siirtyy menneiltä sukupolvilta myös vastuu. Suuret tulot eivät ole omia vaan tulevat siirtymään jälleen seuraavalle sukupolvelle. Vaikka suuromaisuuksia perustellaankin myös yhteiskunnallisella edulla, kuten kotimaahan investoimisella ja työpaikkojen luomisella, suvun etu asettuu kuitenkin selkeästi sen edelle. Perijöitä koskeva luku on erityisen mielenkiintoinen, sillä aihepiiriä on käsitelty varsin vähän suomalaista yhteiskuntaa koskevassa keskustelussa.. Lisäksi se myös nostaa esiin esimerkiksi huippuvarakkaiden sukujen next generation -järjestelmät, eli sukujen nuorille räätälöidyt koulutusjärjestelyt, joilla heitä valmistellaan ja sitoutetaan perintöomaisuuden hoitamiseen. Teoksen 
teemaksi asetetun yhteiskunnallisen eriytymisen näkökulmasta tämänkaltainen toiminta on hyvin kiinnostavaa.

Teoksen toinen pääluku analysoi suurituloisimman promillen näkemyksiä suomalaisesta yhteiskunnasta, sen kehittämisestä sekä heidän käytettävissään olevista poliittisen vaikuttamisen tavoista. Lisäksi kysymys verotuksesta saa oman alalukunsa. Suurituloisimman promillen poliittisten näkemysten tutkimus on erityisen tärkeää, sillä, kuten teoksessa kuvataan, he ovat erittäin hyvin edustettuina poliittisen ja yhteiskunnallisen vaikuttamisen avainpaikoilla. Erilaisten edunvalvontajärjestöjen ja verkostoitumismahdollisuuksia tarjoavien kerhojen ja yhteisöjen yleiskuvailun lisäksi Kantola ja Kuusela esittävät hyvin mielenkiintoista analyysia niin sanotusta eliitin ydinjoukosta, joka koostuu samanaikaisesti lukuisten suuryritysten ja edunvalvontajärjestöjen johtopaikoilla istuvista henkilöistä. Suurituloisin promille on myös tässä vaikutusvaltaisessa joukossa hyvin edustettuna.

Kantola ja Kuusela ovat tunnistaneet haastatteluista kolme keskeistä yhteiskunnallista teemaa. Ensimmäinen näistä on tietynlainen pettymys nyky-yhteiskuntaan, varsinkin sen demokraattiseen prosessiin, joka nähdään omien etujen ajamiseen tähtäävänä hitaana ja tehottomana päätöksenteon tapana. Myös valtion talouden pitkän aikavälin kehitysnäkymät huolestuttavat haastateltuja laajalti. Mielenkiintoisin havainto kuitenkin on molempiin huoliin liittyvä moraalinen ulottuvuus: puolelta kansalaisista katsotaan puuttuvan niitä moraalisia hyveitä, joita huipputuloiset kokevat itsellään olevan.

Ratkaisuksi näihin ongelmiin huipputuloisten ryhmässä tarjotaan liike-elämästä tuttuja keinoja. Hitaan ja kompromisseihin sekä deliberaatioon jumiutuvan politiikan sijaan haastatteluissa nousee teemaksi tarve keskittää valtaa päätöksenteon virtaviivaistamiseksi, jotta voidaan tehdä "rationaalisia päätöksiä". Ajattelutapaa voisi luonnehtia managerialistiseksi. Kantola ja Kuusela kiinnittävät aiheellisesti huomiota siihen, ettei valtaosa haastatelluista näe demokraattista prosessia eettisesti arvokkaana tai yhteiskunnallista hyvää tuottavana. Samoin valtiontalouden tervehdyttämiseksi suurin osa haastatelluista tarjoaa lääkkeeksi leikkauksia ja sääntelyn purkua.

Teoksesta käydyssä julkisessa keskustelussa ensimmäinen, suurituloisimpien ryhmien itseymmärrystä koskeva pääluku on saanut osakseen verrattain vähän huomiota. Tämä johtunee siitä, etteivät sen yhteydet laajempaan poliittiseen keskusteluun ole niin ilmeiset kuin jälkimmäisen osuuden. Vaikka ensimmäisen pääluvun ote onkin tietyssä mielessä sosiologisempi, sen akateemista ja laajempaa yhteiskunnallista merkitystä ei tulisi aliarvioida. Ilman itseymmärryksen ja yhteiskuntamoraalisten näkemysten taustaa huipputuloisen promillen keskuudessa vallalla olevia diskursseja ja pyrkimystä niiden toteuttamiseen politiikassa on vaikea hahmottaa kattavasti. Kantolan ja Kuuselan itselleen asettamien tavoitteiden osalta teoksen ensimmäisen osion voi lopulta katsoa olevan jopa merkityksellisempi, sillä se pureutuu syvemmälle yhteiskunnallisen eriytymisen kysymykseen.

Kuten sanottu, Huipputuloiset on herättänyt poikkeuksellisen runsasta, joskaan ei aina erityisen hyvin informoitua keskustelua hyvästä tieteestä ja erityisesti tutkimusmetodeista. Tämä on toki ymmärrettävää jo siksi, että teoksen käsittelemät kysymykset yhteiskunnallisesta oikeudenmukaisuudesta ja tulonjaosta ovat sekä perustavanlaatuisia että hyvin ajankohtaisia. Lisäksi keskustelun intohimoisuutta voi selittää lukijoiden psykologinen taipumus käsittää tekstissä lainattavat haastateltavat alitajuisesti yhdeksi henkilöksi. Tällöin lainauksissa esiintyvät ristiriitaiset väitteet, esimerkiksi maksettujen verojen suuruuden alleviivaaminen ja aggressiivisen 
verosuunnittelun hyväksyminen, vaikuttavat erityisen epärehellisiltä tai valheellisilta, herättäen voimakkaan tunnereaktion. Huipputuloisten ryhmän ulkopuolinen lukija pöyristyy, kun taas tutkimukseen osallistuneet ovat ilmaisseet julkisuudessa pettymystään siitä, etteivät asiat, joista he ovat kertoneet seikkaperäisesti, ole päässeet teokseen lainkaan.

Huipputuloisten lukeminen vaatiikin lukijalta tietynlaista kurinalaisuutta, sillä tutkimuksessa sovellettu metodi on pidettävä mielessä läpi teoksen. Temaattinen analyysi nostaa esiin nimenomaan aineistossa toistuvia seikkoja. Niiden esittelyyn on valittu parhaiten asiaa kuvastavia lainauksia, jotka usein ovat provokatiivisuuteen asti suoraviivaisia. Analyysia on avattu tarkemmin teoksen lopussa olevassa liitteessä, mutta sitä oltaisiin voitu esitellä seikkaperäisemmin jo johdannossakin. Joka tapauksessa itse tutkimuksen toteutuksessa ei sinänsä ole tässä suhteessa moitittavaa. Teosta on myös syytä kehua poikkeuksellisen laadukkaasta fyysisestä toteutuksestaan. Pienenä erikoisuutena voi mainita runsaat marginaalimerkinnät, joiden avulla tiheästi käytetyistä lainauksista on mahdollista helpommin paikantaa haluamansa.

Johdannossa Kantola ja Kuusela mainitsevat yhdeksi tutkimuskysymykseksi sen, ovatko huipputuloiset eriytymässä omaksi, kansainvälisesti orientoituneeksi sosiaaliseksi ryhmäkseen. Tämä jää teoksen heikoimmin kehittyneeksi teemaksi, vaikka siihen teoksen lopuksi palataankin. Tämä johtuu suurelta osin siitä, että vastaus osoittautuu kaksijakoiseksi. Kansainvälisyys ei esiinny teoksessa ideaalina tai kotimaan kanssa kilpailevana sosiaalisena kontekstina, vaan globalisaation mukanaan tuomana realiteettina, joka on huomioitava investoinneissa sekä johtajien ja osakkaiden tuloja suhteutettaessa.

Teoksen keskeisemmät löydökset koskevat sitä, millä tavalla huipputuloisin promille on edelleen kiinnittynyt kotimaahansa. Keskeiset diskurssit ovat huoli ja eräänlainen moraalinen närkästys yhteiskunnalliseksi vastapuoleksi käsitettyä laiskojen ja yhteiskunnan voimavaroja tuhlaavien joukkoa kohtaan. Kantola ja Kuusela puhuvatkin empatiakuilusta (ks. myös Kainulainen ja Saari 2018). Teoksen perimmäinen vahvuus onkin sen tavassa tuoda esiin syviä normatiivisia näkemyksiä, joille sen tutkiman, monin tavoin vaikutusvaltaisen ryhmän yhteiskunnalliset näkemykset perustuvat. Tässä tehtävässä Huipputuloiset onnistuu hyvin.

\section{LÄHTEET}

Kainulainen, Sakari ja Saari Juho. 2018. Samassa veneessä: empatiakuilujen poliittinen ulottuvuus Suomessa. Politiikka 60:4, 310-323.

Määttänen, Juuso. 2019. Tutkittiinko rikkaiden ajatuksia oikein? Tutkimus huipputuloisista aiheutti arvosteluryöpyn, näin tutkimusmenetelmien asiantuntija arvioi. Helsingin sanomat, 5.9.2019. https:// www.hs.fi/kulttuuri/art-2000006228558.html. Viitattu 12.2.2020.

Pursiainen, Heikki. 2019. Mitä rikkaat todella ajattelevat, osa 2: Kun tiedettä julkaistaan sanomalehdessä. Mustread.fi, 15.10.2019. https://www.mustread.fi/artikkelit/mita-rikkaat-todella-ajattelevat-osa-2kun-tiedetta-julkaistaan-sanomalehdessa/. Viitattu 12.2.2020.

Siilasmaa, Risto. 2019. 745 henkilön kohdejoukosta löytyy 90, jotka suostuvat haastatteluun [...]. Twitter (@rsiilasmaa), 2.9.2019. https://twitter.com/rsiilasmaa/status/1168510174732214272?s=20. Viitattu 12.2.2020. 


\section{KIRJOITTAJATIEDOT}

MIKKO RÄKKÖLÄINEN

YTM, väitöskirjatutkija

Johtamisen ja talouden tiedekunta

Tampereen yliopisto

Mikko.Rakkolainen@tuni.fi 